\title{
The Educational Role of Library: Information Literacy, Competence, and Standards
}

\author{
Marija Jović \\ Gradska knjižnica "Don Mihovil Pavlinović”, Imotski, Croatia
}

\begin{abstract}
This paper deals with the educational role of library, especially university library, and in connection to this, information literacy, competence, and standards in information science. Microcomputers and their current application allow students to use them in laboratories, lecture halls, and libraries; software that are so developed that they allow to various types of computers (micros, picos, or hand-held computers) easy integration with larger systems. In this context libraries, as institutions become one of several available nodes in the information network, the new organization of teaching requires that teachers and students are computer literate requires libraries to provide methods and techniques for handling, through expert systems, their diverse searches, and similar (video disc, for example). Along with terms informatics and information science, there is also the term informatology which denotes theory and practice of emission, transmission, accumulation, selection, and absorption of information, the so-called ETAKSA complex. This paper, therefore, will be discussed communication and communication processes in university libraries that take place using new types of media, which we jointly referred to as information science and in the sea of definitions; we can say that we have added another.
\end{abstract}

Keywords: education, university libraries, computer science, informatology, information literacy

\section{Introduction}

Information science, the consequence of which is the so-called virtual reality; we can also define as a communication process of information exchange through the agreed sign system. It is also a process of sending information to itself or to any other entity, most often through the language. The word communication literally means to make something general or common. It is usually described according to three major dimensions: content, form, and objective. Together, the content and form of communication create messages that are sent towards the objective.

It is indisputable that we find ourselves in a period when it is necessary to change traditional structures in university libraries to adapt to the influences from the environment.

In the development of the information sciences so far, disciplinary convergence was essentially followed by occurrences at two levels: On one level, it was significant that leading experts in the aforementioned disciplines sought to find the most appropriate solutions to similar and general problems, though in their work, they proceeded from different objectives and created a different terminological apparatus; on the second level, special importance of electronic computers and telecommunications in information activities can be emphasized. Their introduction did not only mean the ability to modernize work in libraries, archives, museums,

Marija Jović, Dr., Gradska knjižnica “Don Mihovil Pavlinović”. 
documentation, and information centres, but also influenced the purposeful connecting of different operations and amplified bibliographic control and availability of funds world-wide. When it comes to the influence of computers and telecommunications on information activities, it is necessary to highlight the emergence of a series of new organizational, political, legal, ethical, and economic problems that are caused by computerized and networked systems. But on the other hand, it points to the unjustified neglect of philosophical, epistemological, linguistic, and similar problems in the field of socio-humanistic relations.

\section{Education via the Internet}

Many computers have files with free access to information and their range varies from library catalogues, texts of old books, and collections of various software to games and operating systems.

Some authors warn, as Internet education has increased so much, that library buildings are almost unnecessary. E-learning has "put the last nail in the librarian's coffin" (Gayton, 2008, p. 61).

Apart from standard communication via web, we can also be educated. The term "typical student" can imply the term "traditional student" (Budd, 2005).

At the Department of Information Sciences at the Faculty of Humanities and Social Sciences in Zagreb, for example, today operate Divisions for archivistics and documentation, librarianship, social-humanity informatics, book and publishing, lexicography and encyclopaedia, museology, and knowledge organization.

These are at first glance different professions, but all together they have a common thrust-professional knowledge as a product of information technology:

- Archivistics and documentation-a digital archive designed to preserve all sorts of archive material no matter what the carrier is and when it was created. The material is digitized, archives are increase without spatial expansion, and they keep the past far more reliable and more faithfully than it was ever possible.

- Librarianship - a digital library for access to the produced library material in the widest sense, construction of network aids for description, storage, access, search, and valuation of materials. Digital libraries are distinguished as a special network service because of the inherent form of the specialty of library material. The book is historically the first mass product of information technology.

- Social-humanities informatics-building and formatting of information space and establishing network services for access and management of network resources.

- Book and publishing-knowledge and skills for the application of information technology in the production of knowledge subjects for digital library, archive, and museum collections.

- Lexicography and encyclopaedia-digital organization of linguistic treasure and entire factual knowledge of the human race. Since knowledge carriers have always been books, they are still appreciated knowledge subjects together with the library science which handles them.

- Museology - a digital museum with the purpose of presenting and describing museum objects. World museum collections in digital form preserve material and indirectly spiritual heritage of mankind. In information science, it is considered that every imaginable subject can be a carrier of message or information. Museum objects are a direct proof of this claim.

- Knowledge organization-includes the methodology of the mentioned areas and describes knowledge subjects and shows accompanying development of the area and technology. We believe that precisely the organization of knowledge will, in one way, consolidate all these areas, i.e., build an acceptable common 
ground. Studying and teaching about knowledge subjects in the future will also be approached in a similar way, regardless of whether it is archive material, library material, museum objects, or network service. ${ }^{1}$

Teaching contents are presented to students through the Internet. The basic requirement is that they have a computer with an Internet connection. So-called Courseware tools are used, which allow saving of educational content on the Web Server and their connecting, communication among the participants of the educational process, examining knowledge through various tests just for checking and similar.

The contemporary higher education library is primarily focused on providing services to the users-students and scientific-teaching staff, and for the last 50 years, there has been an increasing pressure on universities and higher education libraries in their composition to respond to ever more numerous and complex demands from the wider social environment (Petrak \& Aparac-Jelušić, 2005).

Education based on the web is done by publishing the content for learning on the web portal (Internet presentation) of an educational institution.

Advantages of material distribution: rapid distribution, students access the offered material through the Internet, multimedia content can be included, service can be used by individuals or groups, at the same time, the possibility to administer the access, and similar.

Rapid development of the Internet and computer technology in the last couple of years has had an impact on changing the traditional learning methods. Now, there are so-called virtual classrooms and virtual education. The university was a central place to which the students had to travel to receive information and instruction. Today, students are already attending classes online without leaving their home. They no longer have to be physically present at the lectures for the acquisition of new information and new knowledge. Lectures and examinations are increasingly being conducted over the Internet. Today, classical classroom is replaced with virtual classrooms, i.e., computer, mouse, and Internet-based learning systems. Many accepted well virtual classrooms. They promise education to many people to whom the possibility of education has been denied or insufficient due to geographic, economic, or other physical reasons.

\section{Advantages and Disadvantages}

Some of the advantages of education via the Internet are:

- It provides fast and easy access to education;

- Getting knowledge and information is done by using a mouse;

- 24-hour access to information;

- It reduces the cost of education, as for those who want to be educated, as well as for institutions that finance education and also for society as a whole;

- Adopting teaching materials is just as good or better than in traditional classrooms;

- It is easier to get to educational experience and teachers/professors;

- Increased learning through cooperation between educators and students;

- Improved attitude towards using computers;

- Students are more likely to adopt the offered material;

- Students who are actively cooperating are more satisfied;

\footnotetext{
${ }^{1}$ Lasić-Lazić, Jadranka, László, Marija, László, Bulcsú, “Konceptualna i primijenjena okosnica studija informacijskih znanosti na Filozofskome fakultetu", Digital Information and Heritage, 1st international science conference "The Future of Information Sciences: INFuture2007-Digital Information and Heritage" Zagreb, 7-9 November 2007, University in Zagreb, pp. 590-591.
} 
- Students who in past had a positive attitude towards using a computer are getting even greater benefit from this type of learning;

- Highly motivated students are more successful at a certain degree of independent work.

However, on the other hand, it raises a series of rhetorical questions of learning efficiency via web:

- Are the programs through which the students acquire knowledge in virtual classrooms sufficiently adequate, and can this kind of education provide enough knowledge and information to the learner?

- Will the quality of learning be lost through the lack of professors and the direct interaction between professors and students?

- Is the direction of movement towards virtual education a dangerous development that can lead to damaging of individuals and society?

- Will virtual education convert the learning process into a mechanical process?

- Are the lessons and information obtained through virtual education adequate to the lessons that a student can receive in lectures of professors?

Responses differ from one person to another and depend on how much the person is attached to the Internet and such form of education.

Analysis of tools for communication via web. An analysis of tools for communication via web can be performed simultaneously with one to nine people, but the number of people depends on the data transfer rate.

Therefore, the objective of information science is precisely defined from the context of human communication:

Its purpose is to improve the exchange of information among people (Wersig \& Neveling, 1975).

This definition is very general, but it sums up all those definitions which, as the objectives of information science, recognize the studying of (only certain) types of communication processes (e.g., "scientific communication" or "study of written knowledge and its transfer in the widest sense") (Tuđman, Boras, \& Dovedan, 1992).

Sending instant messages. Internet Relay Chat (IRC)—the most popular communication service. Among the youth, it known only as "chat", which allows the exchange of only textual messages with other people around the world. It can be of a private or public character and it has the ability to create private communication that requires a password that users write if they want to enter the communication.

Information science has developed from the problem of information explosion or what Vannevar Bush defined more than half a century ago (1945) as a problem of "astonishing amount of knowledge". Bush proposed the application of modern information technology as a solution to the problem. The information science has fully accepted this solution. Information has become the fundamental phenomenon of information science, but not any kind of information. When the 1950s pioneers of information science developed systems and processes for information retrieval, the main objective was to retrieve relevant information (Saračević, 2006).

ICQ Pro is a way of getting in touch with other people. We need an account which we create for free on the ICQ server and we get the so-called ICQ number. With ICQ, we can search for and communicate with any person in the world who has the same account. Part of the communication display serves to send instant messages and part is an address book that we put users into and in which we can see users that are active (online) or inactive (offline). Similarly, you can use chats, send SMS messages, send and receive w-mail messages, transfer files, etc. It is interesting that ICQ uses about 160 million users in more than 245 countries since it was launched in November of 1996. 
MSN Messenger is a program for communication with people connected to the Microsoft Network (MSN) network, i.e., which have a created account called NET Passport, created for free on the Microsoft Network Server. Like similar programs for instant messaging, MSN also supports chats, sending e-mail, file transfer, and conducting of audio and video conferencing, and similar.

Yahoo! Messenger is a program for diverse communication between people all over the world who are connected to the Yahoo network. You also need to create an account that Yahoo! offers for free. Other features are the same as other programs for sending instant messages. You can use chats, send e-mail messages, share files, conduct audio and video conferences and similar.

The appearance of the user screen does not differ from other similar programs: A part of the window is for writing messages that are immediately displayed on the screen, users who are involved in the communication are shown, and if the video conference option is activated, we have a special window in which is the picture of the user with which we communicate if he has a webcam.

\section{Parallel Approaches to Virtual Space}

As a unique communication medium, the Internet contains various subcultures that become the site of discussions about their radical deconstructive effects on the category of identity and generally culture. According to many contemporary theories, the Internet provides users with the opportunity to be what they have always wanted, and to visualize and experience fantasy of alternative identity through the cyber universe.

Precisely because the Internet provides full anonymous communication, many people choose to participate in it in their anonymous roles, which in turn, represent a fantasy over motivation for real social contact.

Windows has become a powerful metaphor to think of itself as a distribution system that is capable of simultaneously exist in different ways and play different roles at the same time.

\section{Identity Problem}

In theory on the construction of identity in the culture of simulation, experiences on the Internet become prominent, but can only be understood in a wider cultural context.

The context represents the thesis on the erosion of boundaries between real and virtual, animated and unanimated, unified, and multiplied self.

Precisely because Internet allows completely anonymous communication, many people decide to participate in it in their anonymous roles. It must be acknowledged that the Internet culture neglects the nature of user motivation, as well as the issue of social status, education, nationality, etc. According to some theoreticians in day-to-day practice of many computer users, Windows has become a powerful metaphor for simultaneous existence in different ways and to play different roles at the same time.

\section{Internet and Delimitation Problem}

The qualities of Internet communication that largely represent the backbone of forming or moving the boundaries of meaning are divided into three categories:

- Socio-technical: Argument, which can be found in virtually all studies dealing with the cyber-universe phenomenon, is contained in the thesis that technology, i.e., new electronic media, are most directly involved in cultural change, inter alia, also because technology itself emerges as a product of social relationships from which it also depends. 
- Real-virtual: One of the major phenomena that moves within a new communication model is moving of the boundaries between real and virtual. The Internet may just look like a virtual reality, since it possesses a specific reality, like any other object in the ranks of hard social conventions.

- Public-private: The difference between private and public can be considered from a perspective of textual discourse, which is one way of self-expression, as well as from a self-explanatory perspective on graphically designed "home page".

\section{Virtual Space and Problem of Meaning}

It can be said that information produces meaning, but that it fails to prevent the sudden loss of meaning in all powers. Despite the ever-increasing IT network that multiplies the contents, decaying of the content happens faster than its re-injection. And precisely in this fact is contained the free-word ideology, i.e., the media reduced to innumerable individual show stations, pirated sites and private programs. In another sense, it can be said that the information does not really have anything in common with meaning, since it represents an operating model of another type, in which Shenon's thesis is contained in one pure instrumental sphere of information, a technical medium that does not have to imply any meaningful purpose.

In his study, J. Beudrillard also assumes the third possibility that the information directly destroys or neutralizes meaning and significance. In his opinion, losing of the meaning is directly related to the dissolving share of information, the media, which opposes the idea that socialization can be measured by the degree of exposure to media messages.

But instead of producing meaning, Baudrillard believes, information consumes its contents, consuming at the same time the communication itself, and thus also social understanding, for two reasons:

- instead of realizing communication, the information is exhausted in making sense.

- behind this hard-to stage communication, the information systems continue unstoppable de-structuring of social understanding.

According to Baudrillard's opinion, all contents of meaning are absorbed in one dominant form of media. People in relation to modern media are in a specific situation. At the same time, they are required to be constituted as autonomous, responsible and conscious subjects and to be constituted as submissive, obedient, and customized objects.

In this situation, man is forced to respond with a double strategy.

\section{Conclusion}

By developing of information technology and creating a computer network, i.e., Internet, a new way of communicating is enabled. With its appearance, the Internet has introduced big changes in all aspects of society and life. The data and information regarding the Internet, which we encounter on a daily basis, do not represent nothing else but true facts, indicating that the Global Network, which connects people, i.e., the whole world, has a tremendous importance and is really used for many purposes, either business, either private. In particular, libraries as reference centres of knowledge gathering have come to the fore. In fact, the fear of the disappearance of the library buildings due to the introduction of the so-called e-learning is completely irrational.

A human factor which gathers the knowledge in libraries will never cease to be necessary.

The Internet, as a widely used medium today, puts other traditional media, such as television, print media, such as newspapers, magazines, and radio, into the second plan, in the sense of increasing and massive use of 
Internet in comparison to the traditional media. The companies are deciding to expand their business to the Internet because this communication channel is available for 24 hours a day, they can choose with who they want to communicate and how, having in mind that online communication is much faster and cheaper, which is important for every company. Unlike the old obsolete communication model, which has imposed restrictions on communication users, such as space and time, communication over the Internet or web communication, has disrupted these limitations.

It enables better access to a variety of information sources around the world, as well as direct communication with all internet users. Now, unlike a one-way communication model, an individual can replace the role of an active participant in the communication process. Participant is given a great opportunity to be informed and socially developed in all aspects of life (regardless if it is education or business character). The Internet as a new medium, which defines the basic parameters of the formation and development of society, has become the medium of digital society communication that has a major impact on the development of the community, and especially the libraries.

\section{References}

Aparac-Gazivoda, T. (1990). Sveučilišni bibliotečni sustavi u teoriji i praksi. Vjesnik bibliotekara Hrvatske, 33(1/4), 43-52.

Basili, C. (2008). Theorems of information literacy. In A. Vraneš, L. J. Marković, and G. Aleksander (Eds.), Informaciona pismenost i doživotno učenje/uredili (pp. 46-78). Beograd: Filološki Fakultet Univerziteta Bibliotekarsko Društvo/Srbije: Emporija Niverzitet.

Budd, J. M. (2005). The changing academic library: Operations, culture, environments. Chicago: ACRL.

Castells, M. (2000). Uspon umreženog društva. Informacijsko doba: Ekonomija, društvo i kultura (Svezak 1). Zagreb: Golden Marketing.

Dizdar, S. (2008). Informacijska pismenost i cjeloživotno učenje: II savjetovanje visokog obrazovanj. Plenarni referati Primjena Bolonjskih principa. Univerzitetu u Sarajevu Sarajevo 11. i 12. April.

EACEA. (2009). TESE (The thesaurus for education systems in Europe). Dostupno na http://eacea.ec.europa.eu/education/eurydice/tese_en.php

Gayton, J. T. (2008). Academic libraries: "Social" or "communal"-The nature and future of academic libraries. Journal of Academic Librarianship, 34(1), 60-66.

Information Literacy Competency Standards for Higher Education. Dostupno na

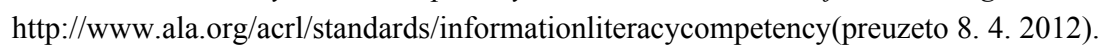

Kranjec, I. (2005). Promjena paradigme u informacijskoj službi pod utjecajem novih tehnologija. Zagreb: Zavod za Informacijske Studije.

Laszlo, M., \& Lasić-Lazić, J. (2011). Merila informacione (ne)pismenosti: Standardizacija i kvalitet bibliotečkih usluga [organizator konferencije Bibliotekarsko društvo Srbije]. Beograd: Bibliotekarsko Društvo Srbije.

Lipovčan, S. (2006). Mediji-druga zbilja. Zagreb: Hrvatska Sveučilišna Naknada.

Petrak, J., \& Aparac-Jelušić, T. (2005). Knjižnice na hrvatskim sveučilištima: Tradicija i promjene. Vjesnik bibliotekara Hrvatske, 48, 13-30.

Prensky, M. (2005). Digitalni urođenici, digitalne pridošlice Razmišljaju li doista drugačije? Edupoint. Dostupno na http://edupoint.carnet.hr/casopis/32/clanci/2 (preuzeto 23.12.2011).

Rašidović, B. E. (2011). Informacijska pismenost i visokoškolske biblioteke-edukacija korisnika: Model Univerziteta u Sarajevu. Sarajevo: Filozofski Fakultet.

Saračević, T. (2006). Prilozi utemeljenju informacijske znanosti. Osijek: Filozofski fakultet.

Secker, M. A. A humanistic approach to information literacy training: The programme at the Commonwealth Scientific and Industrial Research Organisation (CSIRO). Dostupno na http://www.une.edu.au/sat/pdf/CSIROliteracy.pdf (preuzeto 04.04.2011).

Špiranec, S. (2008). Mihaele Banek Zorica.Informacijska pismenost: Teorijski okvir i polazišta. Zagreb: Zavod za Informacijske Studije. 
Tuđman, M. (2006). Informacijska znanost predmet, ishodišta, osnovni pojmovi. Uvod u informacijske znanosti. Retrieved from http://dzs.ffzg.unizg.hr/text/Obavijest\%20i\%20znanje/oiz.pdf

Tuđman, M. (2011). Epistemologijski postav informacijske znanosti. Uvod u informacijske znanosti. Retrieved from http://dzs.ffzg.unizg.hr/text/Obavijest\%20i\%20znanje/oiz.pdf

Tuđman, M., Boras, D., \& Dovedan, Z. (1992). Uvod u informacijske znanosti. Zagreb: Školska knjiga.

Vicković, S. L., \& Alek Z. D. (2009). Ishodi učenja-priručnik za sveučilišne nastavnike. Osijek: SveučilišteJosip Juraj Strossmayer. Dostupno na http://www.unios.hr/uploads/49ishodi\%20ucenja_prirucnik.pdf (9.4. 2012).

Vrdoljak, T. (2010). Jezik i komunikacija. Drvo Znanja: Enciklopedijski Časopis Za Mlade.

Wersig, G., \& Neveling, U. (1975). The phenomena of Information Science. The Information Scientist, 9(4), 127-140. 